\title{
Web Accessibility, Libraries, and the Law
}

With an abundance of library resources being served on the web, researchers are finding that disabled people oftentimes do not have the same level of access to materials as their nondisabled peers. This paper discusses web accessibility in the context of United States' federal laws most referenced in web accessibility lawsuits. Additionally, it reveals which states have statutes that mirror federal web accessibility guidelines and to what extent. Interestingly, fewer than half of the states have adopted statutes addressing web accessibility, and fewer than half of these reference Section 508 of the Rehabilitation Act or Web Content Accessibility Guidelines (WCAG) 1.0. Regardless of sparse legislation surrounding web accessibility, librarians should consult the appropriate web accessibility resources to ensure that their specialized content reaches all.

magine you are a student. In one of your classes, a teacher and librarian create a webpage that will help the class complete an online quiz. This quiz constitutes 20 percent of your final grade. Through the exercise, your teacher hopes to instill the importance of quality research resources found on the web. The teacher and librarian divide their hand-picked resources into five subject-based categories. Each resource listing contains a link to that particular resource followed by a paragraph of pertinent background information. The list concludes with a short video tutorial that prepares students for the layout of the online quiz.

Neither the teacher nor the librarian has extensive web design experience, but they both have basic HTML skills. The library's information technologists give the teacher and librarian web space, allowing them to freely create their content on the web. Unfortunately, they do not have a web librarian at their disposal to help construct the page. They solely rely on what they recall from previous web projects and visual layouts from other websites they admire.

As they begin to construct the page, they first style each category's title with font tags to make them bolder and larger than the surrounding text. They then separate each resource and its accompanying description with the equivalent of hard returns (or line breaks). Next, they place links to the resources within the description text and label them with "Search this resource." Finally, they create the audiovisual tutorial with a runtime of three minutes.

Camilla Fulton (cfulton2@illinois.edu) is Web and Digital Content Access Librarian, University of Illinois, Urbana-Champaign.
As a typical student, you are able to scan the resources and descriptions, familiarize yourself with the quiz's format, and follow the link to the quiz with no inherent problems. Everything on the page flows well for you and the content is broken up easily for navigation.

Now imagine that you are legally blind.

You navigate to the webpage with your screen reader, a software device that allows you to surf the web despite your impairment. Ideally, the device gives you equal access to webpages, and you can navigate them in an equivalent manner as your peers. When you visit your teacher's webpage, however, you start experiencing some problems.

For one, you cannot scan the page like your peers because the category titles were designed with font tags instead of heading tags styled with cascading style sheets (CSS). Most screen readers use heading tags to create the equivalent of a table of contents. This table of contents function divides the page into navigable sections instead of making the screen reader relay all page content as a single mass.

Second, most screen readers also allow users to "scan" or navigate a page by its listed links. When you visit your teacher's page, you get a list of approximately twenty links that all read, "Search this resource." Unfortunately, you are unable to differentiate between the separate resources without having the screen reader read all content for the appropriate context.

Third, because the resources are separated by hard returns, you find it difficult to differentiate between each listed item. Your screen reader does not indicate when it approaches a list of categorized items, nor does it pause between each item. If the resources were contained within the proper HTML list tags of either ordered or unordered (with subsequent list item tagging), then you could navigate through the suggested resources more efficiently (see figures 1,2 , and 3 ).

Finally, the video tutorial's audio tract explains much of the quiz's structure; however, the video relies on image-capture alone for page orientation and navigation. Without a visual transcript, you are at a disadvantage. Stylistic descriptions of the page and its buttons are generally unhelpful, but the page's textual content, and the general movement through it, would better aid you in preparation for the quiz.

To be fair, your teacher would already be cognizant of your visual disability and would have accommodated your class needs appropriately. The Individuals with Disabilities Education Act (IDEA) mandates educational institutions to provide an equal opportunity to education. ${ }^{1}$ Your teacher would likely avoid posting any class materials online without being certain that the content was fully accessible and usable to you. Unlike educational institutions, however, most libraries are not legally bound to the same law. IDEA does not command libraries to provide equal access to information through 
their websites. Neither does the federal government possess a carte blanche web accessibility law that applies to the nation. This absence of legislation may give the impression of irrelevance, but as more core components of librarianship migrate to the web, librarians should confront these issues so they can serve all patrons more effectively.

This article provides background information on the federal laws most frequently referenced within web accessibility cases. Additionally, this article tests three assumptions:

- Although the federal government has no web accessibility laws in place for the general public, most states legalized web accessibility for their respective state agencies.

- Most state statutes do not mention Section 508 of the Americans with Disabilities Act (ADA) or acknowledge World Wide Web Consortium (W3C) standards.

- Most libraries are not included as entities that must comply with state web accessibility statutes.

Further discussion on why these issues are important to the library profession follows.

\section{Literature Review}

No previous study has systematically examined state web accessibility statutes as they relate to libraries. Most articles that address issues related to library web accessibility view libraries as independent entities and run accessibility evaluators on preselected library and university websites. ${ }^{2}$ Those same articles also evaluate the meaning and impact of federal disability laws that could drive the outcome of web accessibility in academia. ${ }^{3}$ In examining state statutes, additional complexities may be unveiled when delving into the topic of web accessibility and librarianship.

\section{Background}

With no definitive stance on public web accessibility from the federal government, states became tasked with providing specifics on when those standards should apply. For example, Section 508 of the Rehabilitation Act could serve as a blueprint for information technology guidelines that state agencies should follow. Section 508 states that

Federal employees with disabilities [must] have access to and use of information and data that is comparable to the access and use by Federal employees who are not individuals with disabilities, unless an undue burden would be imposed on the agency. ${ }^{4}$

Section 508 continues to outline how the declaration should be met when procuring and managing software, websites, telecommunications, multimedia, etc. Section 508's web standards comply with W3C's Web Content Accessibility Guidelines (WCAG) 1.0; stricter compliance is optional.

States could stop at Section 508 and only make web accessibility laws applicable to other state agencies. Section 504 of the Rehabilitation Act, however, provides additional legislation to model. In Section 504, no disabled person can be excluded from programs or activities that are funded by federal dollars. ${ }^{5}$ Section 504 further 
delineates specific entities subject to the auspice of this law. Though Section 504 never mentions web accessibility specifically, states could freely interpret and apply certain aspects of the law for their own use (e.g., making organizations receiving state funds create accessible websites to prevent the exclusion of disabled people).

If states wanted to provide the highest level of service to all, they would also consider incorporating the most recent $\mathrm{W} 3 \mathrm{C}$ recommendations. The W3C formed in 1994 to address the need for structural consistency across multitudinous websites and web browsers. The driving principle of the $\mathrm{W} 3 \mathrm{C}$ is to make the benefits of the web accessible to all, "whatever their hardware, software, network infrastructure, native language, culture, geographical location, or physical or mental ability." 6 The most recent W3C guidelines, WCAG 2.0, detail web accessibility guidelines that are simpler to understand and, if followed, could improve both accessibility and usability despite browser type.

Alternatively, states could decide to wait until the federal government mandates an all-encompassing law on web accessibility. The National Federation of the Blind (NFB) and American Council of the Blind (ACB) have been trying commercial entities in courts, claiming that inaccessible commercial websites discriminate against disabled people. The famous NFB lawsuit against Target provided a precedent for other courts to acknowledge; commercial entities should provide an accessible means to purchase regularly stocked items through their website (if they are already maintaining one). ${ }^{7}$ These commercial web accessibility lawsuits are often defended with Title II and Title III of the ADA.

Title II, Section 202 states,

Subject to the provisions of this title, no qualified individual with a disability shall, by reason of such disability, be excluded from participation in or be denied the benefits of the services, programs, or activities of a public entity, or be discriminated by any such entity. ${ }^{8}$ stylesheet.

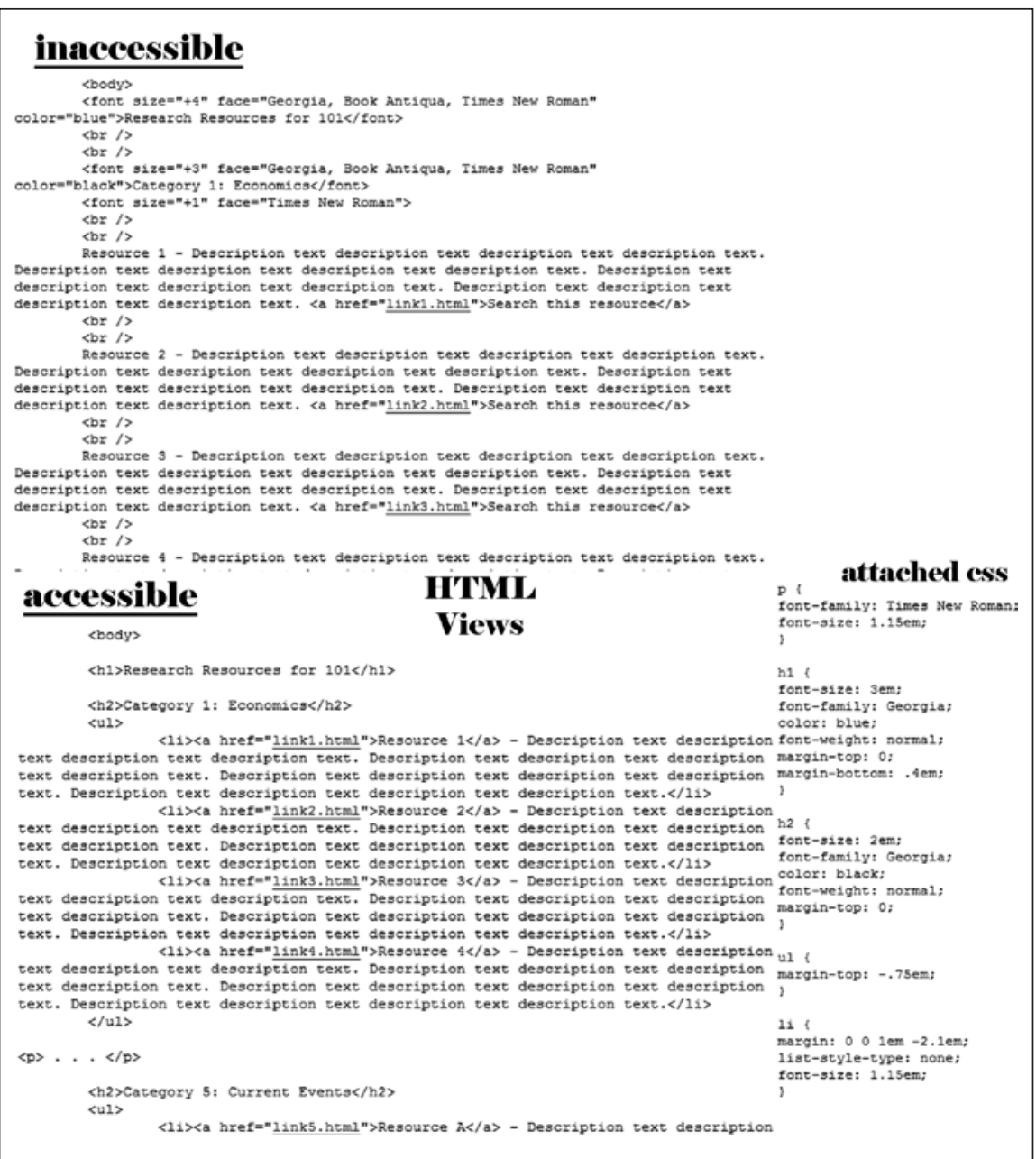

Figure 2. Here we see distinct variances in the source code. The image at the top (inaccessible) reveals code that does not use headings or unordered lists for each resource. The image on the bottom (accessible) does use semantically correct code, maintaining the same look and feel of the headings and list items through an attached cascading

Title II, Section 201 (1) defines "public entity" as state and local governments, including their agencies, departments, and districts. ${ }^{9}$ Title III, Section 302(a) builds on Title II and states that in the case of commercial facilities,

No individual shall be discriminated against on the basis of disability in the full and equal enjoyment of the goods, services, facilities, privileges, advantages, or accommodations of any place of public accommodation by any person who owns, leases . . . or operates a place of public accommodation. ${ }^{10}$ 


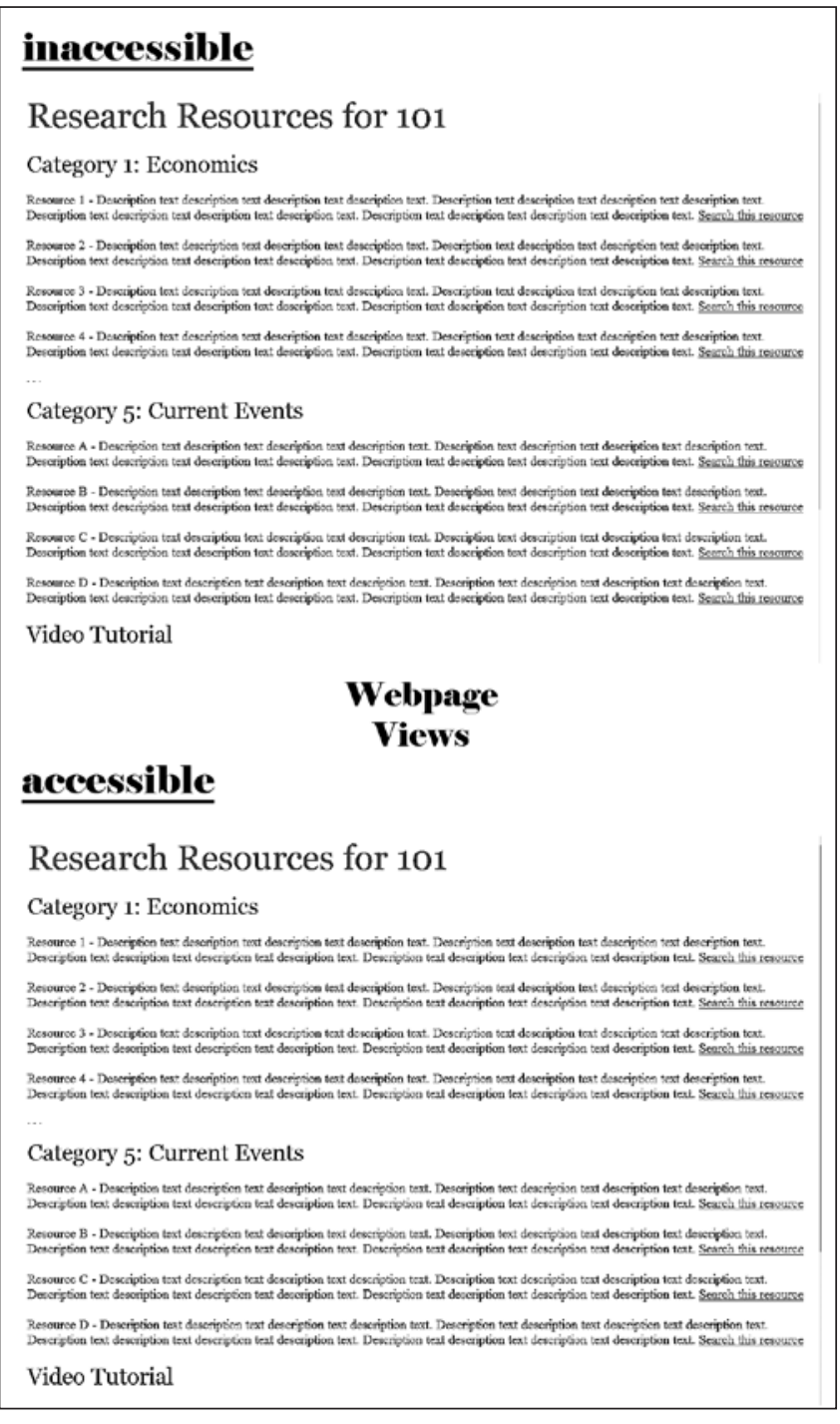

Figure 3. Fangs (http://www.standards-schmandards.com/ projects/fangs/) visually emulates what a standard screen reader outputs so that designers can take the first steps in creating more accessible content on the web.

This title's proclamation seems clear-cut; however, legal definitions of "public accommodation" differ. Title III, Section 301(7) defines a list of acceptable entities to receive the title of "public accommodation."11 Among those listed are auditoriums, theaters, terminals, and educational facilities. Courts using Title III in defense for web accessibility argue that the web is a place, and therefore cannot discriminate against those with visual, motor, or mental disabilities. ${ }^{12}$ Those arguing against using Title III for web accessibility believe that Section 301(7) specifically denotes places of physical accommodation because the authors' original intent did not include virtual ones. ${ }^{13}$ Settling on a definition for "public accommodation" is so divisive that three district courts are receptive to "public accommodation" referring to nonphysical places, four district courts ruled against the notion, and four have not yet made a decision. ${ }^{14}$ Despite legal battles within the commercial sector, state statute analysis shows that states felt compelled to address web accessibility on their own terms.

\section{Method}

This study surveys the most current state statute web presences as they pertain to web accessibility and their connection to libraries. Using Georgia Institute of Technology's State E\&IT Accessibility Initiatives database and Golden's article on accessibility within institutions of higher learning as starting points, I searched each state government's online statutes for the most recently available code. ${ }^{15}$ Examples of search terms used include "web accessibility," "information technology," and "accessibility -building -architecture -health." "Building," for example, excluded statute results that pertained to building accessibility. I then reviewed each statute to determine whether its mandates applied to web accessibility. Some statutes excluded mention of web accessibility but outlined specific requirements for an institution's software procurement.

When statutes on web accessibility could not be found, additional searches were conducted for the most recently available web accessibility guidelines, policies, or standards. Using a popular web search engine and the search terms "[state] web accessibility" usually resulted in finding the state's standards online. If the search engine did not offer desirable results, then I visited the appropriate state government's website. The term "web accessibility" was used within the state government's site search.

The following results serve only as a guide. Because of the ever-changing nature of the law, please consult legal advisors within your institution for changes that may have occurred post article publication.

\section{Results}

"Although the federal government has no web accessibility laws in place for the general public, most states legalized web accessibility for its respective state agencies."

False-Only seventeen states have codified laws ensuring web accessibility for their state websites. ${ }^{16}$ Four 
of these seventeen extended coverage to include agencies receiving state funds (with no exceptions). ${ }^{17}$ Though that number seems disappointingly low, many states addressed web accessibility through other means. Thirtyone states without web accessibility statutes posted some form of standard, policy, or guideline online in its place (see appendix). These standards only apply to state entities, however, and have no legal footing outside of federal law to spur enforcement. At the time of article submission, Alaska and Wyoming were the only two states without an accessibility standard, policy, or guideline available on the web.

"Most state statutes do not mention Section 508 of the Americans with Disabilities Act or acknowledge World Wide Web Consortium (W3C) standards"

True-Interestingly, only seven of the seventeen states with web accessibility statutes reference Section 508 or WCAG 1.0 directly within their statute text (see appendix). ${ }^{18}$ Minnesota is the only state that references the more current WCAG 2.0 standards. ${ }^{19}$ These numbers may seem minuscule as well, but all states have supplemented their statutes with more descriptive guidelines and standards that delineate best practices for compliance (see appendix). Within those guidelines and standards, Section 508 and WCAG 1.0 get mentioned with more frequency.

\begin{abstract}
"Most libraries are not included as entities that must comply with state web accessibility statutes."

True-From the perspective of a librarian, the above data means that forty-eight states would require web accessibility compliance for their state libraries (see appendix). Four of those states (Arkansas, California, Kentucky, and Montana) require all libraries receiving state funds to maintain an accessible website. ${ }^{20} \mathrm{An}$ additional four states (Illinois, Oklahoma, Texas, and Virginia) explicitly hold universities, and therefore their libraries, to the same standards as their state agencies. ${ }^{21}$ Despite the commendable efforts of eight states pushing for more far-reaching web accessibility, thousands of $\mathrm{K}-12$, public, and academic libraries nationwide escape these laws' reach.
\end{abstract}

\section{Discussion and Conclusion}

Without legal backing for web accessibility issues at all levels, "equitable access to information and library services" might remain a dream. ${ }^{22}$ Notably, researchers have witnessed web accessibility improvements in a four-year span; however, as of 2006, even libraries at institutions with ALA-accredited library and information science programs did not average an accessibility validation of 70 percent or higher. ${ }^{23}$ Additionally, a survey of Carnegie classified institutions with library websites found that less than half of each degree-producing division was directed by their institution to comply with the ADA for web accessibility. ${ }^{24}$ Some may not recognize the significance of providing accessible library websites, especially if they do not witness a large quantity of accommodation requests from their users. Coincidentally, perceived societal drawbacks could keep disabled users from seeking the assistance they need..$^{25}$

According to American Community Survey terminology, disabilities negatively affecting web accessibility tend to be sensory and self-care based. ${ }^{26}$ The 2008 American Community Survey Public Use Microdata Sample estimates that 10,393,100 noninstitutionalized Americans of all ages live with a hearing disability and 6,826,400 live with a visual disability. ${ }^{27}$ According to the same survey, an estimated 7,195,600 noninstitutionalized Americans live with a self-care disability. In other words, nearly 24.5 million people in the United States are unable to retrieve information from library websites unless web authors make accessibility and usability their goal.

As gatekeepers of information and research resources, librarians should want to be the first to provide unrestricted and unhindered access to all patrons despite their ability. Nonetheless, potential objections to addressing web accessibility can deter improvement:

Learning and applying web accessibility guidelines will be difficult. There is no way we can improve access to disabled users in a way that will be useful.

Actually, more than 90 percent of sensory-accessibility issues can be resolved through steps outlined in Section 508 , such as utilizing headings properly, giving alternative image descriptions, and providing captions for audio and video. Granted, these elements may be more difficult to manage on extensive websites, but wisely applied web content management systems could alleviate information technology units' stress in that respect. ${ }^{28}$

Creating an accessible website is time consuming and resource draining. This is obviously an "undue burden" on our facility. We cannot do anything about accessibility until we are given more funding.

The "undue burden" clause seen in Section 508 and several state statutes is a real issue that government officials needed to address. However, individual institutions are not supposed to view accessible website creation as an isolated activity. "Undue burden," as defined by the Code of Federal Regulations, relies upon the overall budget of the program or component being developed..$^{29}$ Claiming an "undue burden" means that the institution must extensively document why creating an accessible website would cause a burden. ${ }^{30}$ The institution would also have to provide disabled users an alternative means of access to information provided online. 
No one will sue an institution focused on promoting education. We will just continue providing one-on-one assistance when requested.

In 2009, a blind student, backed by the NFB, initiated litigation against the Law School Admissions Council (LSAC) because of the inaccessibility of its online tests. ${ }^{31}$ In 2010, they added four law schools to the defense: University of California Hastings College of the Law, Thomas Jefferson School of Law, Whittier Law School, and Chapman University School of Law. ${ }^{32}$ These law schools were added because they host their application materials on the LSAC website..$^{33}$ Assuredly, if instructors and students are encouraged or required to use library webpages for assignments and research, those unable to use them in an equivalent manner as their peers may pursue litigation for forcible change.

Ultimately, providing accessible websites for library users should not be perceived as a hassle. Sure, it may entail a new way of thinking, but the benefits of universal access and improved usability far outweigh the frustration that users may feel when they cannot be self-sufficient in their web-based research. ${ }^{34}$ Regardless of whether the disabled user is in a $\mathrm{K}-12$, college, university, or public library, they are paying for a service that requires more than just a physical accommodation..$^{35}$ Federal agencies, state entities, and individual institutions are all responsible (and important) in the promotion of accessible website construction. Lack of statutes or federal laws should not exempt libraries from providing equivalent access to all; it should drive libraries toward it.

\section{References}

1. Individuals with Disabilities Education Act of 2004, 40 U.S.C. §1411-§1419.

2. See David Comeaux and Axel Schmetzke, "Accessibility Trends among Academic Library and Library School Web Sites in the USA and Canada," Journal of Access Services 6 (Jan.-June 2009): 137-52; Julia Huprich and Ravonne Green, "Assessing the Library Homepages of COPLA Institutions for Section 508 Accessibility Errors: Who's Accessible, Who's Not and How the Online WebXACT Assessment Tool Can Help," Journal of Access Services 4, no. 1 (2007): 59-73; Michael Providenti and Robert Zai III, "Web Accessibility at Kentucky's Academic Libraries," Library Hi Tech 25, no. 4 (2007): 478-93.

3. Ibid.; Michael Providenti and Rober Zai III, "Web Accessibility at Academic Libraries: Standards, Legislation, and Enforcement," Library Hi Tech 24, no. 4 (2007): 494-508.

4. 29 U.S.C. $\$ 794(d) ; 36$ Code of Federal Regulations (CFR) $\S 1194.1$.

5. 29 U.S.C. $\S 794$.

6. World Wide Web Consortium, "W3C Mission," http:// www.w3.org/Consortium/mission.html (accessed Jan. 28, 2010).

7. National Federation of the Blind v. Target Corp., 452 F. Supp. 2d 946 (N.D. Cal. 2006).

8. 42 U.S.C. $\S 12132$.
9. 42 U.S.C. $\$ 12131$.

10. 42 U.S.C. $\$ 12182$.

11. 42 U.S.C. $\$ 12181$.

12. Carrie L. Kiedrowski, "The Applicability of the ADA to Private Internet Web Sites," Cleveland State Law Review 49 (2001): 719-47; Shani Else, "Courts Must Welcome the Reality of the Modern Word: Cyberspace is a Place under Title III of the Americans with Disabilities Act," Washington \& Lee Law Review 65 (Summer 2008): 1121-58.

13. Ibid.

14. Nikki D. Kessling, “Why the Target 'Nexus Test' Leaves Disabled Americans Disconnected: A Better Approach to Determine Whether Private Commercial Websites are 'Places of Public Accommodation,'" Houston Law Review 45 (Summer 2008): 991-1029.

15. State E \& IT Accessibility Initiatives Workgroup, "State IT Database," Georgia Institute of Technology, http://acces sibility.gtri.gatech.edu/sitid/state_prototype.php (accessed Jan. 28, 2010); Nina Golden, "Why Institutions of Higher Education Must Provide Access to the Internet to Students with Disabilities," Vanderbilt Journal of Entertainment \& Technology Law 10 (Winter 2008): 363-411.

16. Arizona Revised Statutes $\S 41-3532$ (2010); Arkansas Code of 1987 Annotated §25-26-201-\$25-26-206 (2009); California Government Code §11135-\$11139 (2010); Colorado Revised Statutes §24-85-101-§24-85-104 (2009); Florida Statutes §282.601§282.606 (2010); 30 Illinois Complied Statutes Annotated 587 (2010); Burns Indiana Code Annotated §4-13.1-3 (2010); Kentucky Revised Statutes Annotated §61.980-§ 61.988 (2010); Louisiana Revised Statutes §39:302 (2010); Maryland State Finance and Procurement Code Annotated §3A-311 (2010); Minnesota Annotated Statutes §16E.03 Subdivisions 9-10 (2009); Missouri Revised Statutes §191.863 (2009); Montana Code Annotated §185-601 (2009); 62 Oklahoma Statutes §34.16, §34.28-\$34.30 (2009); Texas Government Code §2054.451-\$2054.463 (2009); Virginia Code Annotated §2.2-3500-\$2.2-3504 (2010); West Virginia Code $\S 18-10 \mathrm{~N}-1-\S 18-10 \mathrm{~N}-4$ (2009).

17. Arkansas Code of 1987 Annotated §25-26-202(7) (2009); California Government Code $§ 11135$ (2010); Kentucky Revised Statutes Annotated §61.980(4) (2010); Montana Code Annotated $\S 18-5-602$ (2009).

18. Arizona Revised Statutes $\$ 41-3532$ (2010); California Government Code §11135(d)(2) (2010); Burns Indiana Code Annotated §4-13.1-3-1(a) (2010); Florida Statutes §282.602 (2010); Kentucky Revised Statutes Annotated §61.980(1) (2010); Minnesota Annotated Statutes §16E.03 Subdivision 9(b) (2009); Missouri Revised Statutes §191.863(1) (2009).

19. Minnesota Annotated Statutes §16E.03 Subdivision 9(b) (2009).

20. Arkansas Code of 1987 Annotated §25-26-202(7) (2009); California Government Code $\$ 11135$ (2010); Kentucky Revised Statutes Annotated §61.980(4) (2010); Montana Code Annotated $\S 18-5-602$ (2009).

21. 30 Illinois Complied Statutes Annotated 587/10 (2010); 62 Oklahoma Statutes \$34.29 (2009); Texas Government Code §2054.451 (2009); Virginia Code Annotated §2.2-3501 (2010).

22. American Library Association, "ALAhead to 2010 Strategic Plan," http:/ / www.ala.org/ala/aboutala/missionhistory / plan/2010/index.cfm (accessed Jan. 28, 2010).

23. Comeaux and Schmetzke, "Accessibility Trends." 
24. Ruth Sara Connell, "Survey of Web Developers in Academic Libraries," Journal of Academic Librarianship 34, no. 2 (2008): 121-29.

25. Patrick M. Egan and Traci A. Guiliano, “Unaccommodating Attitudes: Perceptions of Students as a Function of Academic Accommodation Use and Test Performance" North American Journal of Psychology 11, no. 3 (2009): 487-500; Ramona Paetzold et al., "Perceptions of People with Disabilities: When is Accommodation Fair?" Basic \& Applied Social Psychology 30 (2008): 27-35.

26. U.S. Census Bureau, American Community Survey, Puerto Rico Community Survey: 2008 Subject Definitions (Washington, D.C.: Government Printing Office, 2009). Hearing disability pertains to deafness or difficulty in hearing. Visual disability pertains to blindness or difficulty seeing despite prescription glasses. Self-care disability pertains to those whom have "difficulty dressing or bathing."

27. U.S. Census Bureau, Data Set: 2006-2008 American Community Survey (ACS) Public Use Microdata Sample (PUMS) 3-Year Estimates (Washington, D.C.: Government Printing Office, 2009). For a more interactive table, with statistics drawn directly from the American Community Survey PUMS data files, see the database created and maintained by the Employment and Disability Institute at Cornell University: M. J. Bjelland, W. A. Erickson, and C. G. Lee, Disability Statistics from the American Community Survey (ACS), Cornell University Rehabilitation Research and Training Center on Disability Demographics and Statistics (StatsRRTC), http://www.disabilitystatistics.org (accessed Jan. 28, 2010).

28. Sébastien Rainville-Pitt and Jean-Marie D'Amour, "Using a CMS to Create Fully Accessible Web Sites," Journal of Access Services 6 (2009): 261-64; Laura Burzagli et al., "Using Web Content Management Systems for Accessibility: The Experience of a Research Institute Portal," in Proceedings of the 11th International Conference on Computers Helping People with
Special Needs, vol. 5105, Lecture Notes in Computer Science (Linz, Australia: Springer-Verlag, 2008) 454-61; David Kane and Nora Hegarty, "New Site, New Opportunities: Enforcing Standards Compliance within a Content Management System," Library Hi Tech 25, no. 2 (2007): 276-87.

29. 28 CFR $\S 36.104$.

30. Ibid.

31. Sheri Qualters, "Blind Law Student Sues Law School Admissions Council Over Accessibility," National Law Journal (Feb. 20, 2009), http://www.law.com/jsp/nlj/PubArticleNLJ .jsp?id=1202428419045 (accessed Jan. 28, 2010). Follow the case at the County of Alameda's Superior Court of California, available online (search for case number RG09436691): http://apps .alameda.courts.ca.gov/domainweb/html/index.html (accessed Sept. 20, 2010).

32. Ibid.

33. Ibid. After finding the case, click on "Register of Actions" in the side navigation menu. These details can be found on page 10 of the action "Joint Case Management Statement Filed," uploaded June 30, 2010.

34. Jim Blansett, "Digital Discrimination: Ten Years after Section 508, Libraries Still Fall Short of Addressing Disabilities Online," Library Journal 133 (Aug. 2008): 26-29; Drew Robb, "One Site Fits All: Companies are Working to Make Their Web Sites Comply with Accessibility Guidelines because the Effort Translates into More Customers," Computerworld (Mar. 28, 2005): 29-32.

35. The United States Department of Justice supports Title III's application of "public accommodation" to include virtual web spaces. See U.S. Department of Justice, "Settlement Agreement Between the United States of America and City of Missoula County, Montana Under the Americans with Disabilities Act," DJ\# 204-44-45, http://www.justice.gov/crt/foia/mt_1.php and http://www.ada.gov/missoula.htm (accessed Jan. 28, 2010).

\section{Appendix. Library Website Accessibility Requirements, by State}

\begin{tabular}{|c|c|c|c|c|}
\hline State & $\begin{array}{l}\text { Libraries } \\
\text { Included? }\end{array}$ & Code & Online State Statutes & $\begin{array}{l}\text { Online Statements/Policies/ } \\
\text { Guidelines }\end{array}$ \\
\hline Ala. & $\mathrm{n} / \mathrm{a}$ & $\mathrm{n} / \mathrm{a}$ & $\mathrm{n} / \mathrm{a}$ & $\begin{array}{l}\text { http://isd.alabama.gov/isd/statements } \\
\text {.aspx }\end{array}$ \\
\hline Alas. & $\mathrm{n} / \mathrm{a}$ & $\mathrm{n} / \mathrm{a}$ & $\mathrm{n} / \mathrm{a}$ & $\mathrm{n} / \mathrm{a}$ \\
\hline Ariz.* & $\begin{array}{l}\text { state and } \\
\text { state- } \\
\text { funded (with } \\
\text { exceptions) }\end{array}$ & $\begin{array}{l}\text { Arizona Revised } \\
\text { Statutes } \$ 41- \\
3532\end{array}$ & $\begin{array}{l}\text { http://www.azleg.state.az.us/ } \\
\text { ArizonaRevisedStatutes.asp? } \\
\text { Title=41 }\end{array}$ & http://az.gov/polices_accessibility.html \\
\hline Ark. & $\begin{array}{l}\text { state and } \\
\text { state-funded }\end{array}$ & $\begin{array}{l}\text { Arkansas Code } \\
\text { Annotated } \$ 25- \\
26-201 \text { thru } \\
\S 25-26-206\end{array}$ & $\begin{array}{l}\text { http://www.arkleg.state.ar.us/assembly/ } \\
\text { ArkansasCodeLargeFiles/Title\%2025\%20 } \\
\text { State\%20Government-Chapter\%2026\%20 } \\
\text { Information\%20Technology.htm and http:// } \\
\text { www.arkleg.state.ar.us/bureau/Publications/ } \\
\text { Arkansas\%20Code/Title\%2025.pdf }\end{array}$ & $\begin{array}{l}\text { http://portal.arkansas.gov/Pages/policy } \\
\text {.aspx }\end{array}$ \\
\hline
\end{tabular}




\section{Appendix. Library Website Accessibility Requirements, by State (continued)}

\begin{tabular}{|c|c|c|c|c|}
\hline State & $\begin{array}{l}\text { Libraries } \\
\text { Included? }\end{array}$ & Code & Online State Statutes & $\begin{array}{l}\text { Online Statements/Policies/ } \\
\text { Guidelines }\end{array}$ \\
\hline Calif.* & $\begin{array}{l}\text { state and } \\
\text { state-funded }\end{array}$ & $\begin{array}{l}\text { California } \\
\text { Government } \\
\text { Code } \$ 11135 \\
\text { thru } \$ 11139\end{array}$ & http://www.leginfo.ca.gov/calaw.html & $\begin{array}{l}\text { http://www.webtools.ca.gov/Accessibility/ } \\
\text { State_Standards.asp }\end{array}$ \\
\hline Conn. & $\mathrm{n} / \mathrm{a}$ & $\mathrm{n} / \mathrm{a}$ & $\mathrm{n} / \mathrm{a}$ & http://www.access.state.ct.us/ \\
\hline Del. & $\mathrm{n} / \mathrm{a}$ & $\mathrm{n} / \mathrm{a}$ & $\mathrm{n} / \mathrm{a}$ & $\begin{array}{l}\text { http://gic.delaware.gov/information/ } \\
\text { access_central.shtml }\end{array}$ \\
\hline Ga. & $\mathrm{n} / \mathrm{a}$ & $\mathrm{n} / \mathrm{a}$ & $\mathrm{n} / \mathrm{a}$ & $\begin{array}{l}\text { http://www.georgia.gov/00/static/ } \\
\text { 0,2085,4802_0_0_Accessibility, 00.html }\end{array}$ \\
\hline Hawaii & $\mathrm{n} / \mathrm{a}$ & $\mathrm{n} / \mathrm{a}$ & $\mathrm{n} / \mathrm{a}$ & $\begin{array}{l}\text { http://www.ehawaii.gov/dakine/docs/ada } \\
\text {.html }\end{array}$ \\
\hline Idaho & $\mathrm{n} / \mathrm{a}$ & $\mathrm{n} / \mathrm{a}$ & $\mathrm{n} / \mathrm{a}$ & http://idaho.gov/accessibility.html \\
\hline III. & $\begin{array}{l}\text { state and } \\
\text { university }\end{array}$ & $\begin{array}{l}30 \text { Illinois } \\
\text { Complied } \\
\text { Statutes } \\
\text { Annotated } 587\end{array}$ & http://www.ilga.gov/legislation/ilcs/ilcs.asp & $\begin{array}{l}\text { http://www.dhs.state.il.us/page.aspx? } \\
\text { item=32765 }\end{array}$ \\
\hline Kans. & $\mathrm{n} / \mathrm{a}$ & $\mathrm{n} / \mathrm{a}$ & $\mathrm{n} / \mathrm{a}$ & $\begin{array}{l}\text { http://www.kansas.gov/about/ } \\
\text { accessibility_policy.html }\end{array}$ \\
\hline Ky.* & $\begin{array}{l}\text { state and } \\
\text { state-funded }\end{array}$ & $\begin{array}{l}\text { Kentucky } \\
\text { Revised } \\
\text { Statutes } \\
\text { Annotated } \\
\$ 61.980 \text { thru } \\
\$ 61.988\end{array}$ & http://www.Irc.ky.gov/krs/titles.htm & $\begin{array}{l}\text { http://technology.ky.gov/policies/ } \\
\text { webtoolkit.htm }\end{array}$ \\
\hline La. & state & $\begin{array}{l}\text { Louisiana } \\
\text { Revised } \\
\text { Statutes } \\
\S 39: 302\end{array}$ & http://www.legis.state.la.us/ & $\begin{array}{l}\text { http://www.louisiana.gov/Government/ } \\
\text { Policies/\#webaccessibility }\end{array}$ \\
\hline Maine & $\mathrm{n} / \mathrm{a}$ & $\mathrm{n} / \mathrm{a}$ & $\mathrm{n} / \mathrm{a}$ & $\begin{array}{l}\text { http://www.maine.gov/oit/accessibility/ } \\
\text { policy/webpolicy.html }\end{array}$ \\
\hline
\end{tabular}




\section{Appendix. Library Website Accessibility Requirements, by State (continued)}

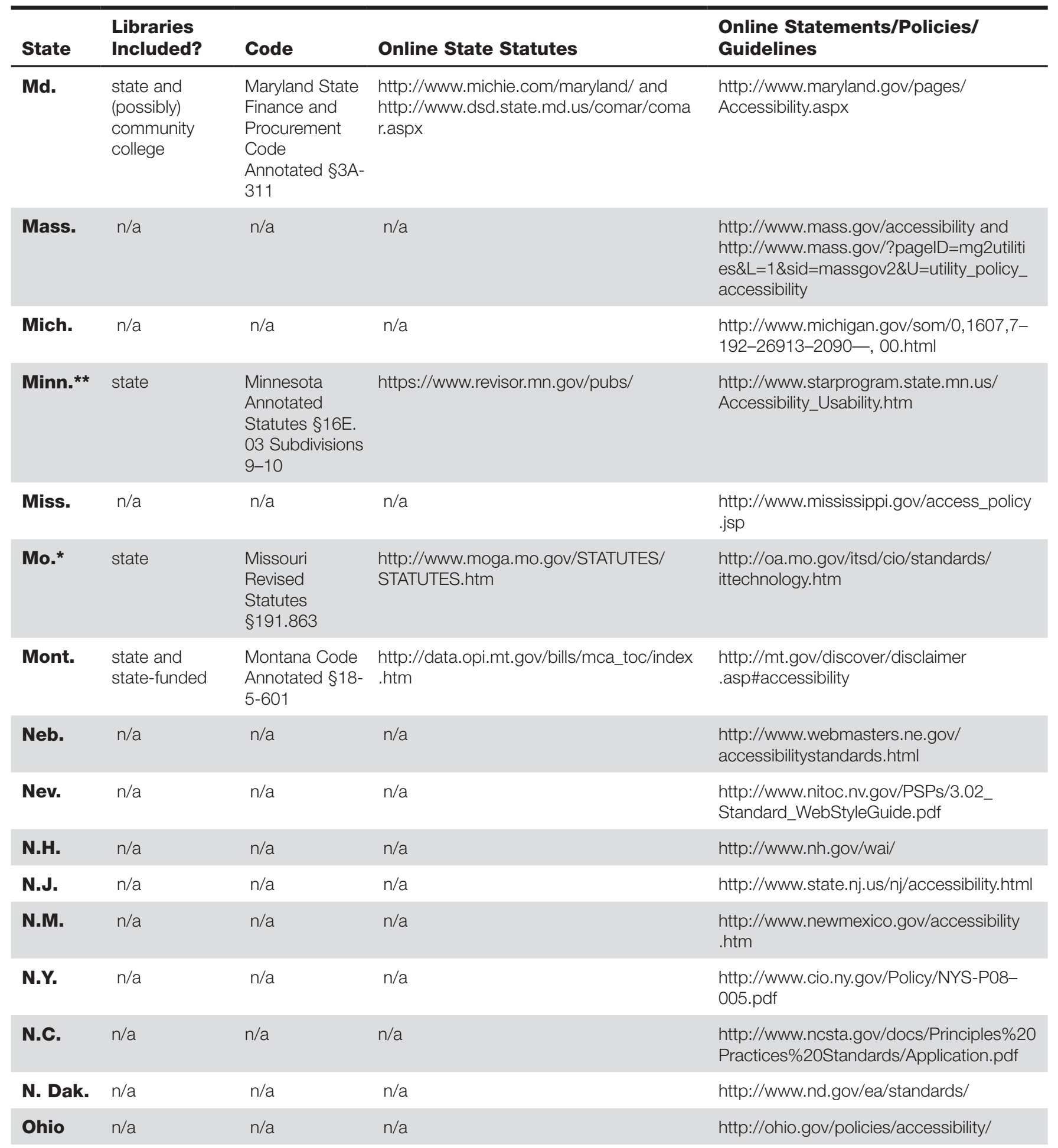




\section{Appendix. Library Website Accessibility Requirements, by State (continued)}

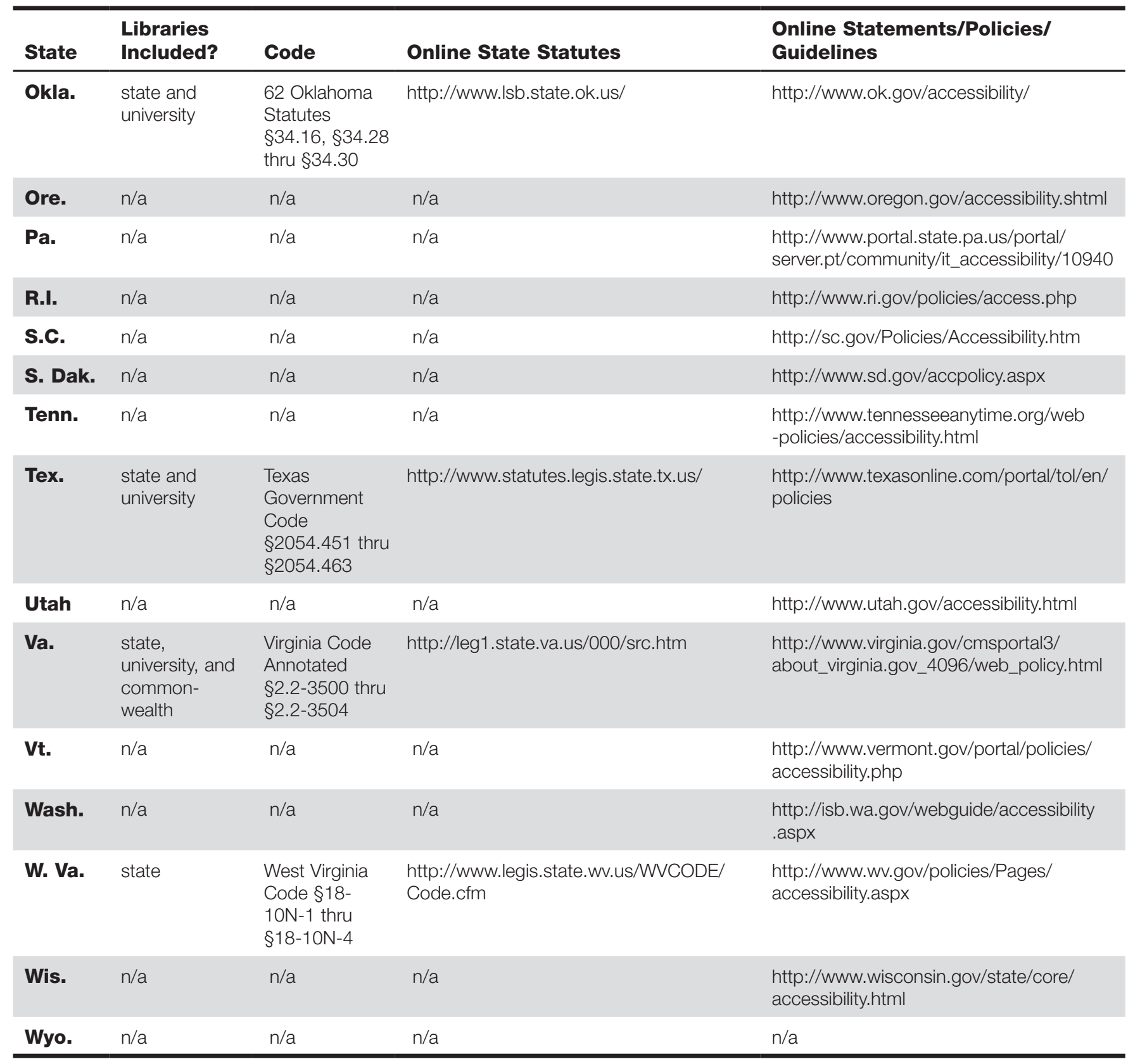

*These states mention Section 508 of the Rehabilitation Act within statute text

**This state mentions WCAG 2.0 within its statute text

Note: Most states with statutes on web accessibility also have statements, policies, and guidelines that are more detailed than the statute text and may contain references to Section 508 and WCAG 2.0. All webpages were visited between January 1, 2010, and February 12, 2010. 